\title{
ASEAN E-Commerce Legal Framework and Alignment of Lao PDR: A Review
}

\author{
Phet Sengpunya \\ University of Pecs, Hungary \\ phetspy@outlook.com
}

\begin{abstract}
In the era of digital, the internet has become a new channel for meeting and social interaction of people all around the world, and it has also become an essential platform for commercial activities, especially ecommerce. E-commerce has become a significant driving force for the growth of the economy for all regions around the world. For example, ASEAN, ICT, and e-commerce are recognized as an essential segment for regional integration. ASEAN developed its legal framework in order to promote and facilitate the development of ICT and the growth of e-commerce within the region. Unlike the European Union, ASEAN is not a supranational organization, and it cannot legislate for a whole community. Thus its ecommerce legal framework is developed by harmonizing the Member Countries' national laws into the regional legal system. This paper aims to introduce how ASEAN designs its legal framework for regional cooperation, with a focus on e-commerce. The paper presents how Lao PDR, as a member country of ASEAN, fulfills provisions agreed under the e-ASEAN framework to help understand the way ASEAN Member Countries undertake action to align with ASEAN e-commerce legal framework. To this end, this paper also provides an overview of the e-commerce of ASEAN as a whole and Lao PDR.
\end{abstract}

KEYWORDS: ASEAN, Lao PDR, E-Commerce Legal Framework, Regional Legal System.

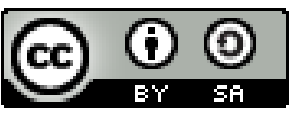

Copyright $\odot 2019$ by Author(s)

This work is licensed under a Creative Commons Attribution-ShareAlike 4.0 International License. All writings published in this journal are personal views of the authors and do not represent the views of this journal and the author's affiliated institutions.

\section{HOW TO CITE:}

Sengpunya, Phet. "ASEAN E-Commerce Legal Framework and Alignment of Lao PDR: A Review" (2019) 6:3 Lentera Hukum 375-396.

Submitted: November 12, 2019 Revised: October 28, 2019 Accepted: December 20, 2019 


\section{INTRODUCTION}

Information and communication technology (ICT) will continue to be the critical force driving nation-building in many aspects in the next few decades. Recently, ASEAN has been brought prosperity and wealth to the region through innovation and technology. At the moment, we can see that the industrial landscape and business worldwide have been significantly changed from the ICT revolution. ICT has changed the nature of product distribution, marketing, advertising, services, and retailing. This change has promised to accelerate e-commerce and other digital innovation. To adapt, to embrace, and to understand ICT and digital opportunities is necessary for economic development in the ICT age.

The rapid growth of e-commerce has presented many essential benefits to consumers and businesses all around the world. ${ }^{l}$ The ASEAN regional cooperation on ICT is being enhanced, and ASEAN Member States have been continuing their effort to improve the ICT infrastructure. ${ }^{2}$ For ASEAN, the development of infrastructure is important, and the organization has established many regional projects, agreements, and studies to foster infrastructure development, including transportation, energy, and ICT. ${ }^{3}$ In 2018, a regional agreement on the e-commerce of ASEAN was signed, aiming to facilitate cross border e-commerce in the region and promote its growth. ${ }^{4}$

E-commerce is a radically new way of conducting commercial activities, and it is potentially a significant driver to increase economic growth and strengthen development around the world. ${ }^{5}$ It helps small and medium-sized enterprises access global markets and compete on an international level. In developing economies and less developed countries, e-commerce has enhanced economic growth and created several new jobs. ${ }^{6}$ For Lao PDR, as one of the least developed countries, the rapid growth of $\mathrm{e}$ commerce in ASEAN and all around the world introduces a low cost of trade for Lao exporters and helps lower prices for consumers. ${ }^{7}$

\section{A. ASEAN E-Commerce and Policy Development}

ASEAN, after China and India, has the third-largest number of internet users in the world, and it is one of the regions that has the fastest growth in internet usage. The significant drivers of growth are its promotion of investment, infrastructure

Competition Commission of Singapore, Handbook on E-Commerce and Competition in ASEAN, (15 February 2019), at 14.

2 ASEAN Investment Report 2018 - Foreign Direct Investment and the Digital Economy in ASEAN, (Jakarta: ASEAN Secretariat, 2018), at 163 .

3 OECD, Structural Policy Country Notes for Emerging Asia - Economic Outlook for Southeast Asia, China, and India 2014: Beyond the Middle-Income Trap, (2013), at 12.

See generally ANNEX A, Factsheet on ASEAN Agreement on Electronic Commerce.

Christine Sanderson, EU Forges Ahead on E-commerce, 11 Int'l Tax Rev. 51 (2000), at 51.

ESCAP, Embracing the E-commerce Revolution in Asia and the Pacific - Executive Summary, (June 2018), at xii.

Marcus Bartley John, Mombert Hoppe, Martin Molinuevo, Konesawang Nghardsysone, and Lillyana Daza-Jaller, Taking Advantage of E-commerce: Legal, Regulatory, and Trade Facilitation Priorities for Lao PDR, World Bank Group (February 4, 2019), at 1. 
development, and regional participation in digital development. ${ }^{8}$ As of June 2018, ASEAN has more than 350 million internet users, and on average, each user spends 4 hours on the mobile internet daily - more than anyone other countries in the world. This evidence could be supported by the fact that more than $50 \%$ of ASEAN's population is under 30 , and they have more significant attraction for technology and internet-based transactions. ASEAN raised more than USD72 billion in 2018, and the ASEAN internet economy is estimated to reach USD240 billion by $2025 .^{9}$ To maintain this growth sustainably, however, the right policy and legal framework are required in order to promote further investment and participation by the private sector, and also to address significant challenges of the growth. ${ }^{10}$

The integration efforts of ASEAN intends to establish a single regional market in order to facilitate free movement of goods, services, and investment, and free flow of capital, as well as free flow of skills across the region ${ }^{11}$ and integration is a significant driver of the digital economy development in ASEAN. In 2015, the ASEAN Economic Community (AEC) was launched, ${ }^{12}$ in which the ICT sector is recognized as a critical driver for regional integration.

Over the last decade, ministers, regulators, policymakers, and industry of ASEAN came and worked together for developing the ICT landscape, as well as the legal framework. ${ }^{13}$ The cooperation of ASEAN on ICT was initiated before 2000, and it started becoming more concrete when an e-ASEAN Framework Agreement to put national laws and policies relating to electronic transactions in place under the agreement. $^{14}$ The Framework Agreement intends to enhance ASEAN's information infrastructure, facilitate the growth of e-commerce, and to foster investments in digital products and services.

Along with the Framework Agreement, successive five-year ICT master plans were also adopted, where the first ASEAN ICT Master Plan was adopted in 2010 aiming at ICT infrastructure development, and bridging the digital divide $\mathrm{e}^{15}$ that requires commitment from the Member Countries to improve the competitiveness of their national ICT sectors. ${ }^{16}$ The more recent ASEAN ICT Master Plan or AIM 2020 was

8 ASEAN Investment Report 2018 - Foreign Direct Investment and the Digital Economy in ASEAN, (Jakarta: ASEAN Secretariat, 2018), at 163.

9 Google TEMASEK, e-Commerce SEA 2018: Southeast Asia Internet Economy Hits an Inflection Point, (2018), at 4.

10 ASEAN Investment Report 2018 - Foreign Direct Investment and the Digital Economy in ASEAN, (Jakarta: ASEAN Secretariat, 2018), at 163.

11 ASEAN, "Invest in ASEAN - Single Market and Production Base," (2019), online: 〈http://investasean.asean.org/index.php/page/view/asean-economiccommunity/view/670/newsid/758/single-market-and-production-base.html>.

12 ASEAN Secretariat, "ASEAN Economic Community", (2019), online: https://asean.org/aseaneconomic-community/s.

13 ASEAN, ASEAN ICT Master Plan, 2015, at 5.

14 Art. 5, the e-ASEAN Framework Agreement.

15 ASEAN Investment Report 2018 - Foreign Direct Investment and the Digital Economy in ASEAN, (Jakarta: ASEAN Secretariat, 2018), at 238; See also ASEAN ICT Masterplan 2015 Completion Report, ASEAN (2015), pp. 8-11; and ASEAN ICT Masterplan 2015, pp. 9-10

16 ASEAN, ICT Masterplan 2015, at 20; and See also Master Plan on ASEAN Connectivity, at 15. 
adopted in 2016, focusing on developing an integrated digital economy more broadly. It aims to drive ASEAN towards a digitally secured, enabled, and transformative economy; and to enable an inclusive, innovative, and integrated ASEAN Community. ${ }^{17}$

In November 2017, ASEAN adopted the Work Programme on Electronic Commerce 2017-2025 in order to strengthen the development of e-commerce within the emerging single market of ASEAN. ${ }^{18}$ The work program aims to develop and implement guidelines, coordination mechanisms, and specific initiatives related to broadband infrastructure, the modernization of e-commerce legal frameworks, consumer protection, trade facilitation, payment systems, the security of electronic transactions, competition, and improved logistics. ${ }^{19}$ It introduces an adoption of an ASEAN agreement on e-commerce intending to enhance cross-border transactions/ecommerce and digital connectivity by laying down trade rules on e-commerce... ${ }^{20}$ Under the Agreement, the ASEAN Member States agree to maintain and adopt laws and regulations governing electronic commerce based on international norms as soon as practicable. $^{21}$

In 2016, ASEAN adopted the ASEAN Framework on Personal Data Protection to ensure recognitions of the importance of personal data protection, accuracy of personal data, and security safeguards within ASEAN. The framework seeks to contribute to the flows of information, and the growth and promotion of regional trade within ASEAN. In addition, the ASEAN Framework on Digital Data Governance is currently being developed, leading by Singapore, in order to harmonize data regulations, and it is expected to be completed in 2019. These two frameworks will also play an essential role in helping promote digital usage, consumer confidence, and the growth of e-commerce within ASEAN. ${ }^{22}$

\section{B. Lao PDR's E-Commerce and Policy Development}

To attain a higher status from the Least Developed Countries list, Lao PDR is actively working to develop its economy, including the digital economy. In the previous six or seven years, Lao PDR has had a noticeable shift in its economic outlook, and the robust growth from 2018 to 2022 will grow at a rate of $7.1 \% .{ }^{23}$ Becoming a member of the WTO and in its pursuit to transform its economy and trade, Lao has turned to services as a driver of economic development. As such, ICT services are gradually recognized as a significant part of the economy of Lao PDR due to its geographical position in ASEAN and the wish to overtake the development of digital economies within its borders.

17 See generally ASEAN ICT Master Plan 2020

18 The Preamble, ASEAN Agreement on Electronic Commerce; See also 〈https://asean.org/aseaneconomic-community/sectoral-bodies-under-the-purview-of-aem/e-Commerce/s.

19 Jakarta: ASEAN Secretariat, Ibid at 239.

20 See ANNEX A, Factsheet on ASEAN Agreement on Electronic Commerce.

21 Art. 5 (1) and (2), ASEAN Agreement on Electronic Commerce.

22 Jakarta: ASEAN Secretariat, Ibid at 239.

23 OECD, Economic Outlook for Southeast Asia, China, and India 2018: Fostering Growth Through Digitalisation, OECD Publishing, Paris (2018), pp. 21 and 45. 
As the only landlocked country in ASEAN, digital technologies offer new channels for Lao people and businesses to integrate with regional and international markets. Hence, the potential for e-commerce as a tool for export diversification is vital for Lao people and businesses, ${ }^{24}$ and e-commerce offers ways of reducing high costs of participating in trade for small firms, increasing participation in trade and survival rates for small firms, and offering greater export diversification in regional and international markets.

Furthermore, Lao PDR, with a favorable geographical situation and politicalsocial stability, has high potential with advantageous conditions to become the communication and transportation hub of the region. Lao PDR is aiming to turn from a Land-locked into a Land-linked country. Borne from this initiative, the construction and operation of the China-Laos Railway is an unusual movement. Upon the completion of the railway, the inland country like Lao PDR will become a transportation center and suitable for the construction of a logistics distribution center. ${ }^{25}$ This development will be attractive to Lao people to start their business in Lao PDR, especially the business in e-commerce.

However, at present, e-commerce is still a new development phase of Lao PDR, and e-commerce activities are quite new for Lao people. The adoption of e-commerce by both consumers and companies remains limited. According to UNCTAD, e-commerce is understood as activities related to purchasing retail products such as IT products, notably clothes and cosmetics online. ${ }^{26}$ The recent growth of the e-commerce of Lao PDR has been contributed by the improvement of logistics and payment infrastructure, as purchasing products online has been consumed more and more by young people. Because of the underdeveloped telecommunications infrastructure and the low usage of banking and credit card, e-commerce is still not broadly used in Lao PDR. ${ }^{27}$ Nonetheless, it has made remarkable progress on trade facilitation.

Over the past ten years, access to telecommunication services has primarily expanded in Lao PDR, especially mobile phone services. Notwithstanding, the continuation of the development of the telecommunication sector still has impediment due to the lack of a licensing framework, an independent regulator, and a level playing field in the market. Other than the growth of mobile connectivity in recent years, Lao PDR also needs to strengthen the Internet service to promote the use of digital financial services (DFS). As of 30 June 2019, Lao PDR had 2.5 million internet users or about $35.4 \%$ of the total population ${ }^{28}$ and more than 80 percent of the population owns a mobile phone, but only 40 percent are using DFS, and the low understanding of

\footnotetext{
24 Marcus Bartley John, Mombert Hoppe, Martin Molinuevo, Konesawang Nghardsysone, and Lillyana Daza- Jaller, Ibid at 29.

25 Zhang Tuo, Yu Hui, and Rong Zhongxia, Report on China-Laos Cooperation Opportunities under the Belt and Road Initiative in 2018, Xinhua Silk Road Department (2018), at 28-29.

26 UNCTAD, Lao People's Democratic Republic: Rapid eTrade Readiness Assessment - Executive Summary, (2018), at viii.

27 Department of Commerce of the US, "US Country Commercial Guides - Laos" (2017), at 14.

28 See <https://www.internetworldstats.com/stats.htm〉.
} 
technology in rural areas is still a significant challenge for the adoption of DFS in Lao PDR. $^{29}$

In order to catch up on the development of e-commerce at ASEAN and the international levels, the government of Lao PDR is currently preparing and working on policies and regulations in order to facilitate and promote the development and the use of e-commerce in Lao PDR. In 2016, the country amended Law on Investment Promotion laying down the legal basis for the development and establishment of Special Economic Zones in Lao PDR, where the Special Economic Zones comprise industrial sectors such as the ICT, trade, services, and tourism sectors. However, the country still has a lack of a full set of laws to govern e-commerce activities. In order to support the growth of e-commerce, Lao PDR is currently considering more specific laws on e-commerce. ${ }^{30}$ Until now, it has adopted a Law on Electronic Transactions ${ }^{31}$, Law on Electronic Signature ${ }^{32}$, Law on $\mathrm{ICT}^{33}$, Law on Prevention and Combating of Cyber Crime ${ }^{34}$, and Law on Payment System, ${ }^{35}$ but the particular protection of consumers online is still not covered by its Law on Consumer Protection.

Currently, there are many initiatives established to enhance the use of ecommerce among SMEs in Lao PDR. For example, Plaosme is a remarkable initiative launched in August 2017. It is an e-commerce platform to foster SMEs in the country in their e-commerce and export capability by offering a digital marketplace, access to trade associations, and business matching across ASEAN. The e-payment service of a state-owned commercial bank - Banque pour le Commerce Extérieur Lao (BCEL) is another initiative to support e-commerce in the country. ${ }^{36}$ BCEL has provided an online payment service, which has allowed businesses to accept payment more flexibly around the world in cooperation with CyberSource - a California-based e-commerce creditcard payment system. Thailand's currency exchange company may also launch another digital platform for e-payment service, foreign exchange, and cash transfers to facilitate e-commerce in Lao PDR - SuperRich soon, in which the platform is in between seeking approval from the Government of Lao PDR. ${ }^{37}$

\section{ASEAN E-COMMERCE LEGAL FRAMEWORK}

In ASEAN, e-commerce has significantly grown in recent years. ASEAN considers ecommerce as a significant contributor to economic growth and regional integration.

29 UNCTAD, Ibid.

30 OECD, ERIA, ASEAN SME Policy Index 2018 - 15. Lao PDR: 2018 ASPI Country Profile, (2018), pp. 301, 304.

31 See hhttps://aoofficialgazette.gov.la/index.php?r=site/display\&eid=447).

32 See htttps://laoofficialgazette.gov.la/index.php?r=site/display\&\&id=1495>.

33 See https://laoofficialgazette.gov.la/index.php?r=site/display\&id=1136».

34 See 〈https://laoofficialgazette.gov.la/index.php?r=site/display\&id=86l〉.

35 See 〈https://laoofficialgazette.gov.la/index.php?r=site/display\&id=1298〉.

36 OECD, ERIA, Ibid at 301.

37 Fintechnews Singapore, "The State of Fintech in Laos" (2017). online: 〈http://fintechnews.sg/9709/laos/fintech-laos/〉. 
Because of this, ASEAN has developed a legal framework to support e-commerce growth in the region. Recently, a public-private sector advisory body was established by ASEAN aiming to develop a broad-based and comprehensive action plan toward evolving an ASEAN e-community. ${ }^{38}$

In the e-commerce legal aspect, ASEAN has continued its effort to develop its legal framework in order to govern e-commerce in the region. The ASEAN Member Countries have started to work together in establishing a legal environment to promote e-commerce growth for years. Its first initiative regarding legal e-commerce development was the adoption of ASEAN Vision 2020 in 1997. This adoption was followed by several plans to introduce legal initiatives concerning e-commerce. For that effort, ASEAN developed a legal framework to facilitate the e-commerce development by harmonizing relevant laws and regulations of the ASEAN Member Countries into the regional legal system. ${ }^{39}$ ASEAN is the first developing region to prepare a harmonized e-commerce legal framework. Its legal harmonization consists of the common objective and principles for e-commerce laws. ${ }^{40}$ Furthermore, ASEAN recently adopted an ASEAN Agreement on e-Commerce in order to deepen e-commerce legal cooperation and promote e-commerce growth in the region.

\section{A. The Development of ASEAN E-Commerce Legal Framework}

The industrialization of ASEAN has been rapidly driven by the Information and communication technologies (ICT) revolution from the 1970s. ASEAN has considered ICT as a critical priority for its regional integration. ${ }^{41}$ By adopting ASEAN Vision 2020 in 1997, ASEAN set forth the initiative on ICT development. Under the ASEAN Vision 2020, ASEAN Member States resolved to accelerate the development of science and technology, including information technology, by establishing a regional information technology network and centers of excellence for the dissemination of and easy access to data and information. ${ }^{42}$ Among others, the ASEAN Vision 2020 aims to make the ASEAN economic region highly competitive, stable, and prosperous in order to foster the free flow of goods, services, capital, and investments, while promoting equitable economic development and reducing poverty and socio-economic disparities within ASEAN by the year 2020. ${ }^{43}$

After the adoption of the ASEAN Vision 2020 and in order to achieve its goals, ASEAN has commenced its effort to establish an e-commerce legal framework aiming

38 Samtani Anil, Electronic Commerce in Asia: The Legal, Regulatory and Policy Issues, Int. Journal of Law and Information Technology, Vol.9 No. 2, Oxford University Press (2001), at 97.

39 Art. 5, e-ASEAN Framework Agreement (2000); See generally ASEAN Economic Community Blueprint 2025 (2015); and ASEAN ICT Masterplan 2015.

40 UNCTAD, Review of E-commerce Legislation Harmonization in the Association of Southeast Asian Nations, (2013), at xi.

41 UNCTAD, Review of E-commerce Legislation Harmonization in the Association of Southeast Asian Nations, (2013), at iii.

42 See generally ASEAN Vision 2020

43 Nazura Abdul Manap, Alignment of Malaysia and ASEAN Agreement on ICT Law: A review. Contemporary Issues in South-East Asia Countries. Brawijaya Law Jornal, Vol. 2(S) No.1 (2015), at 4. 
to promote e-commerce development within the region. The Hanoi Plan of Action was the first Plan to Action launched in 1997, ${ }^{4}$ encouraging ASEAN member countries to create policy and legislative environment to facilitate cross-border e-commerce. This effort ensures the coordination and adoption of framework and standards for cross border e-commerce, which is in line with international standards and practices. It encourages technical cooperation and technology transfers among Member States in the development of e-commerce infrastructure, applications, and services. ${ }^{45}$

Following the Hanoi Plan of Action, another e-ASEAN initiative was endorsed on 28 November 1999, by the ASEAN leaders at their Summit Meeting in Manila, the Philippines. ${ }^{46}$ This means was intended to foster socio-economic development and employment; strengthen information and news worldwide access; provide better government services and promote better governance, and to foster cross-border business and networks. ${ }^{47}$ The e-ASEAN initiative introduced a series of plans that provide measures for establishing a legal framework. It has been a significant initiative of ASEAN to develop a regional legal framework and encouraging member countries to develop their domestic laws and regulations on e-commerce. ${ }^{48}$

On $24^{\text {th }}$ of November 2000, the ASEAN entered into the e-ASEAN Framework Agreement ${ }^{49}$ in which the Framework Agreement consisted of elements focusing on the development of an e-commerce legal and regulatory framework to foster the competitiveness of ASEAN industries and businesses, and establishment of the ASEAN information infrastructure by establishing the national infrastructure and strengthening the connectivity among the Member Countries. ${ }^{50}$ Through the e-ASEAN Framework Agreement, Member Countries adopted their domestic e-commerce law and regulatory framework that established trust and confidence for consumers and facilitated the business's transformation towards the development of e-ASEAN. Specifically, the Framework Agreement provides that Member Countries shall:

1) expeditiously put in place national laws and policies relating to electronic commerce transactions based on international norms;

2) facilitate the establishment of mutual recognition of digital signature frameworks;

44 Rodolfo Noel S. Quimbo, "The e-ASEAN Legal Framework and Its Challenges" Harmonized development of legal and regulatory systems for e-commerce in Asia and the Pacific: Current challenges and capacity-building needs (2012), at 82.

45 ASEAN, "Hanoi Action Plan of Action", 1997 (2.8.1).

46 ASEAN Secretariat, "Toward an e-ASEAN," Online 〈https://www.asean.org/wpcontent/uploads/images/2012/Economic/TELMIN/TOWARD\%20AN\%20E-ASEAN.pdf>.

47 Simon S.C. Tay, Jesus P. Estanislao, Hadi Soesastro, Reinventing ASEAN, Institute of Southeast Asian Studies, Singapore (2001), at 141.

48 UNCTAD, Review of E-commerce Legislation Harmonization in the Association of Southeast Asian Nations Introduction, (2013), at 1.

49 Xiudian Dai, e-ASEAN and Regional Integration in South East Asia, University of Hull, UK (2007), at 416; and See also Art. 2, E-ASEAN Framework Agreement.

50 Simon S.C. Tay, Jesus P. Estanislao, Hadi Soesastro, Reinventing ASEAN, Institute of Southeast Asian Studies, Singapore (2001), at 141. 
3) facilitate secure regional electronic transactions, payments, and settlements, through mechanisms such as electronic payment gateways;

4) adopt measures to protect intellectual property rights arising frome-commerce. Member States should consider the adoption of the World Intellectual Property Organization (WIPO) treaties, namely: "WIPO Copyright Treaty 1996" and "WIPO Performances and Phonograms Treaty 1996";

5) take measures to promote personal data protection and consumer privacy, and

6) encourage the use of alternative dispute resolution (ADR) mechanisms for online transactions. ${ }^{51}$

By the adoption of the above measures, the development of the e-commerce legal framework of ASEAN has significantly progressed. Along with the support of UNCTAD and AusAID/ASEAN projects, more electronic transactions laws of the ASEAN Member Countries were adopted in recent years. ${ }^{52}$

To further promote the legal e-commerce development within the region, ASEAN regulators have also agreed to develop non-binding regulatory models on e-commerce. The regulatory models serve as approaches and guidelines for the ASEAN Member States to use as a common reference to develop new legal and regulatory instruments or to create their respective legal and regulatory systems and processes. ${ }^{53}$ In 2001, it adopted the e-ASEAN Reference Framework for E-commerce Legal Infrastructure intending to provide a guide for helping ASEAN member states that at that time did not have any e-commerce laws in place to draft their own. It also helped ASEAN member states that already have e-commerce laws in place to achieve cross-border e-commerce and the cross-recognition/cross-certification of digital certificates/digital signatures. ${ }^{54}$ The framework is a remarkable regulatory model of ASEAN in order to support Member Countries to develop their e-commerce laws and regulations. It outlines general principles for e-commerce law, which Member Countries must adopt in their domestic law. Key features of the general principles provided by the framework are:

1) They should conform to international standards such as UNCITRAL's Model Law on Electronic Commerce and Draft Model Law on Electronic Signatures to be interoperable with similar laws of other countries;

2) They should be transparent and predictable so that there is no legal ambiguity between transacting parties in an electronic transaction;

3) They should be technology-neutral, with no discrimination between different types of technology;

51 Art. 5, the e-ASEAN Framework Agreement.

52 UNCTAD, Review of E-commerce Legislation Harmonization in the Association of Southeast Asian Nations Executive Summary, (2013), at iv.

53 See Reference Framework for E-commerce Legal Infrastructure 2001, at 1.

54 Rodolfo Noel S. Quimbo, "The e-ASEAN Legal Framework and Its Challenges" Harmonized development of legal and regulatory systems for e-commerce in Asia and the Pacific: Current challenges and capacity-building needs (2012), at 84; And See also Reference Framework for E-commerce Legal Infrastructure 2001, at 1. 
4) They should be media neutral, that is, paper-based commerce and e-commerce are treated equally under the law. ${ }^{55}$

The framework also states the minimum provisions required to be contained in Member Countries' draft laws and regulations on e-commerce. It provides that ecommerce laws should contain provisions on electronic transactions; normal rules of contracts should apply equally to transactions online; the legal effect of using electronic records and electronic signatures; presumptions regarding the reliability of electronic records and electronic signatures; duties of trusted third parties and certification authorities, and relevant rules so; and the extent of legal liability for service providers. ${ }^{56}$ Although significant e-commerce legal development was introduced to ASEAN by entering into the Free Trade Agreements, only AANZFTA provides more detailed provisions on e-commerce.

AJCEP, AIFTA, ACFTA, and AKFTA do not include specific provisions on ecommerce. In fact, they only identify e-commerce as a sector in which parties could strengthen cooperation. ${ }^{57}$ The AANZFTA created a framework for cooperation and coordination on e-commerce. P They aim to promote e-commerce between the parties, to promote the broader use of e-commerce globally, and to enhance cooperation between the parties in order to foster the development of e-commerce. ${ }^{58}$

The AANZFTA remarked a significant e-commerce legal framework for ASEAN. It requires the parties to adopt domestic law and regulations governing electronic transactions $^{59}$ which is a driving force for legal e-commerce development within ASEAN. Under the terms of FTA, the parties, especially ASEAN member states that do not have any e-commerce law, shall adopt domestic laws and regulations that will govern electronic transactions.

The AANZFTA also stipulates that each party shall protect e-commerce consumers $^{60}$, protect the personal data of the e-commerce users ${ }^{61}$, and work on the implementation of initiatives providing paperless trading. It also provides provisions on paperless trading, whereby the parties undertake to make documents of trade administration available in electronic form to the public and to recognize documents transmitted electronically as a legal equivalent of the paper version, taking into account principles recognized by international organizations such as the World Customs

55 See Reference Framework for E-commerce Legal Infrastructure 2001, at 5.

56 See Reference Framework for E-commerce Legal Infrastructure 2001, pp. 7-9; and See also Rodolfo Noel S. Quimbo, "The e-ASEAN Legal Framework and Its Challenges" Harmonized development of legal and regulatory systems for e-commerce in Asia and the Pacific: Current challenges and capacity-building needs (2012), at 88 .

57 Marn-Heong Wong and Marie Isabelle Pellan, Trade Facilitation: The Way Forward for ASEAN and Its FTA Partners, ERIA Policy Brief, No. 2012-04 (July 2012), at 4.

58 Chritopher Findlya, ASEAN and Regional Free Trade Agreements, Routledge London and New York 2015. at 5l; and See also Art. 1 of Chapter. 10, AANZFTA.

59 Art. 4 of Chapter. 10, AANZFTA.

60 Art. 6 of Chapter. 10, AANZFTA.

61 Art. 7 of Chapter. 10, AANZFTA. 
Organization. ${ }^{62}$ Also, in strengthening the promotion and development, the parties of AANZFTA have undertaken to encourage cooperation in the form of research and training on electronic commerce. ${ }^{63}$

Moreover, the ASEAN State Members, apart from an adoption of their national policy and regulations in alignment to the regional frameworks, have participated in WTO Working Programme on E-commerce established in October 1998 in response to the Ministerial Declaration on Global Electronic Commerce that was adopted in May 1998, in order to promote WTO rule-making for e-commerce. However, at the moment, the consensus has not yet been reached by the members of WTO, which the WTO rulemaking on e-commerce is yet to be completed. ${ }^{64}$ And most recently, 2019, six out of ten ASEAN Member States, including Brunei Darussalam, Lao PDR, Malaysia, Myanmar, Singapore, and Thailand, have confirmed their intention together with 70 other members of the WTO to continue negotiation to put in place global rules on electronic commerce. $^{65}$

\section{B. The Current Position of ASEAN E-Commerce Legal Framework}

At the moment, ASEAN does not have any legal superstructure to establish a unified regime that could support regional e-commerce.ASEAN has developed an e-commerce legal framework by complementing the Member Countries' national laws into a regional legal system that respects cultural sensitivities and national sovereignty. ${ }^{66}$ Consequently, the e-commerce legal support of ASEAN depends upon the adoption of a common reference framework that serves as a legal template. This template would provide a guide to help ASEAN Member States enact their domestic laws and regulations on e-commerce in the respective ASEAN jurisdictions. ${ }^{67}$

In respect of the region's aim of economic integration, ASEAN has made progress towards legal harmonization within the region. ${ }^{68}$. Previously, only four ASEAN Countries - Malaysia, Philippines, Singapore, and Thailand - have laws covering ecommerce, based mostly on the model suggested by the UNCITRAL. ${ }^{69}$ With the support of AusAID/ASEAN project and UNCTAD during 2004 to 2009, four new

62 Chritopher Findlya, ASEAN and Regional Free Trade Agreements, Routledge London and New York (2015), at 52; and See also AANZFTA, Art. 8 of Chap. 10.

63 Art. 9 of Chapter. 10, AANZFTA.

${ }^{64}$ Industrial Structure Council, 2017 Report on Compliance by Major Trading Partners with Trade Agreements - WTO, EPA/FTA, and IIA - Part II. WTO Rules and Major Cases - Addendum 3. Ecommerce, the Ministry of Economy, Trade, and Industry, Japan (2017), at 631-634.

65 WTO, Joint Statement on Electronic Commerce, WT/L/1056, (19-0423), Brussels (25 January 2019), at 1. Online: ‘https://trade.ec.europa.eu/doclib/docs/2019/january/tradoc_157643.pdf).

${ }^{66}$ Joanne Wong, On Legal Harmonization Within ASEAN, Juris, Vol. 5 (2013/14) Singapore Law Review (2013), pp. 1-2.

67 Dr. Eliza Mik, Legal and Regulatory Challenges to Facilitating E-Commerce in the ASEAN, at 3.; and See also Pasha L. Hsieh, Bryan Mercurio, ASEAN Law in the New Regional Economic Order: Global Trends and Shifting Paradigms, Cambridge University Press (2019), at 344.

68 Joanne Wong, On Legal Harmonization Within ASEAN, Juris, Vol. 5 (2013/14) Singapore Law Review (2013), at 2.

69 Simon S.C. Tay, Jesus P. Estanislao, Hadi Soesastro, Reinventing ASEAN, Institute of Southeast Asian Studies, Singapore (2001), at 144. 
electronic transactions laws - in Indonesia, Vietnam, Brunei and Myanmar - were implemented $^{70}$. In 2012, law on electronic transactions of Lao PDR was also implemented. ${ }^{71}$ Cambodia is the only ASEAN Member Country that does not have a law on electronic transactions ${ }^{72}$, however, Cambodia is still working on its first e-commerce law. ${ }^{73}$ It is clear that regarding legal harmonization, ASEAN has made significant progress in developing a legal framework for e-commerce within ASEAN.

Furthermore, ASEAN launched the ASEAN Work Programme on E-commerce in November 2017, calling on ASEAN to strengthen coordination and cooperation on ecommerce. This program also prepares an ASEAN Agreement on e-Commerce aiming to facilitate cross-border e-commerce transactions in ASEAN. ${ }^{74}$ The ASEAN Economic Ministers endorsed the Agreement at the 50th ASEAN Economic Ministers Meeting on 29 August 2018, and the Agreement was signed by the ASEAN Economic Ministers on 12 November 2018, on the sidelines of the 33rd ASEAN Summit and Related Meetings. ${ }^{75}$ However, the instruments of ratification for entering into force have not yet been ratified by the Member States.

The adoption of the ASEAN Agreement on E-commerce is an essential development of the regional legal framework on e-commerce for ASEAN in order to increase the use of e-commerce and to enhance economic growth and social development in ASEAN. The main objectives of the Agreement are: to facilitate cross border e-commerce transactions in ASEAN, contribute to establishing a trust and confidence environment in the use of e-commerce in ASEAN, and tighten cooperation to develop further and enhance the e-commerce ASEAN. ${ }^{76}$ Under the ASEAN Agreement on e-Commerce, ASEAN Member Countries work together to establish an environment facilitating cross border e-commerce transactions in the region. It includes advancing the legal framework in e-commerce and establish more excellent digital connectivity across the ASEAN region. ${ }^{77}$

Under the ASEAN Agreement on e-Commerce, ASEAN Member States maintain or adopt laws and regulations governing electronic commerce, taking into account international model law, conventions, principles, or guidelines relating to e-Commerce

70 UNCTAD, Review of E-commerce Legislation Harmonization in the Association of Southeast Asian Nations Executive Summary, (2013), at iv.

71 See Law on Electronic Transaction, Lao PDR. Online 〈https://laoofficialgazette.gov.la/kcfinder/upload/files/Law\%20on\%20Electronic\%20Transactions\%2 0.pdf>.

72 Sum Manet, "E-Commerce Law a Realty Soon," Khmer Times, (7 November 2016). Online 〈https://www.khmertimeskh.com/61899/e-commerce-law-a-realty-soon/〉.

73 Chea Vannak, "E-commerce Law may not pass in 2018: Ministry, "Khmer Times, (3 May 2018). Online 〈https://www.khmertimeskh.com/485822/e-commerce-law-may-not-pass-in-2018-ministry/〉.

74 The Preamble, ASEAN Agreement on Electronic Commerce; and See also UNCTAD, Towards an ASEAN Agreement on Electronic Commerce, Geneva, Switzerland, (2018). Online 〈https://unctad.org/en/pages/MeetingDetails.aspx?meetingid=1730〉.

75 See generally ANNEX A, Factsheet on ASEAN Agreement on Electronic Commerce.

76 Art. 2, ASEAN Agreement on Electronic Commerce.

77 Austrade, Ibid. 
as soon as practicable. ${ }^{78}$ It will further flourish the development of a legal environment for e-Commerce in each Member State and the ASEAN as a whole. ${ }^{79}$ Furthermore, the entry into force of the Agreement would establish a fundamental legal framework for integration of the e-commerce sector of ASEAN in the age of ICTs.

\section{E-COMMERCE LAW IN LAO PDR AND ITS ALIGNMENT TO ASEAN E-COMMERCE LEGAL FRAMEWORK}

E-commerce is growing fast in all regions all around the world. However, in Asia and the Pacific, the legal and institutional environment poses as a key challenge for ecommerce development. Legislation on e-commerce and measures that enable a more affordable and accessible e-commerce participation are still in need of being strengthened. Enacting appropriate legislation and regulations can reduce legal barriers to the use of e-commerce and facilitate cross-border e-commerce transactions. Appropriate legislation is vital for the e-commerce industry in order to promote its growth. Weak or inappropriate legal and regulatory frameworks can reduce the trust in e-commerce transactions, and therefore lower the use of e-commerce. ${ }^{80}$ By recognition of this, the government of Lao PDR is currently preparing and working on the development of an e-commerce legal framework in order to catch up on ASEAN and also the international level.

\section{A. National Policies Related to ICT, E-Government, and E-Commerce}

At present, ICT becomes a critical driving force of socio-economic development for all nations, regional, and international integrations. By this recognition, Lao PDR includes the development of ICT, e-government, and e-commerce at the core of its national development plans. It is now active in implementing its $8^{\text {th }}$ National Socio-Economic Development Plan 2016-2020 (NSEDP), aiming to discharge from LDC status. ${ }^{81}$ The government of Lao PDR adopted NSEDP in April 2016, which reflects its national Socio-economic Development Strategy until 2025 and Vision 2030. These have an objective to discharge from LDC status by 2020 and to become an upper-middleincome country by 2030. Furthermore, the result of the adoption of NSEDP, the development of a digital economy in the country, is strongly promoted ${ }^{82}$ Moreover, it has made significant progress in the development of ICT and the growth of ecommerce.

78 Art. 5 (1) and (2), ASEAN Agreement on Electronic Commerce.

79 See generally ANNEX A Factsheet on ASEAN Agreement on e-Commerce.

80 ESCAP, Embracing the E-commerce Revolution in Asia and the Pacific, (June 2018), pp. 31-32, and its Executive Summary, at xii.

81 See generally $8^{\text {th }}$ Five-year National Socio-Economic Development Plans (2016-2020), Lao PDR - But although the 2020 discharge target is clearly mentioned in the NSEDP (2016-2020), recent Government reports moved the target to 2025 (https://rtm.org.la/nsedp/criteria-ldc-graduation/).

82 UNCTAD, Ibid at 5. 
Lao PDR, seeking to drive the country to the information age, considers the ICT as a significant segment to help it achieve socio-economic development. It increases access to ICT for people countrywide, encourages both domestic and foreign investors to invest in construction and development of ICT infrastructure, promotes research and development in the ICT field, and develops human resources and institutional capacities building. ${ }^{83}$ Overall, it aims to ensure the legal frameworks, sectoral conditions, and institutional and human capacity to be in place for accelerating the ICT field to meet the challenges and needs of Lao PDR. ${ }^{84}$

Furthermore, Lao PDR has adopted a set of laws relevant to e-commerce activities, and it has continued its effort to develop a comprehensive e-commerce legal framework in order to enhance the development of ITC and the growth of e-commerce. It promotes electronic commerce and services and other electronic transactions for developing the economy and serving the society; ${ }^{85}$ promotes the safe, convenient, fast, and righteous cyber consume in order to protect the rights and interests of both cyberservice and electronic information service providers and users; ${ }^{86}$ and it also encourages both private and public sectors to develop and use an electronic signature and electronic seal in their activities, business, and services. ${ }^{87}$

\section{B. Legal and Regulatory Frameworks}

The Government of Lao PDR endeavors to develop a comprehensive set of cyber laws to regulate electronic activities in Lao PDR. ${ }^{88}$ It has taken remarkable effort in the development of e-commerce legal and regulatory framework and has introduced provisions on electronic transactions and the recognition of electronic documents and signatures. It also introduced provisions limiting intermediary liability and provisions maintaining an open regime for the cross-border data flow and data centers localization. ${ }^{89}$

In 2012, the country adopted a new Law on Electronic Transactions, laying down the path for future growth in e-commerce. ${ }^{90}$ The law provides the principles, regulations, and measures for the formation, use, recognition, management, and inspection of electronic transactions to build trust and confidence in electronic transactions. Its main objectives are to protect the legitimate rights and interests of those who are doing electronic commerce; and to ensure the use and promotion of electronic transactions, modernity, regional and international integration for

83 Art. 4, Law on Information and Communication Technology, Lao PDR (2016).

84 Mr. Somlouay KITTIGNAVONG (Acting Director-General of Department of National Authority for Science and Technology), a presentation on ICT Development in Lao PDR - at Expert Group Meeting on regional cooperation on information society in Asia and the Pacific, Bangkok (July 2009).

85 Art. 4, Law on Electronic Transactions, Lao PDR (2012).

86 Art. 4, Law on Prevention and Combating of Cybercrime, Lao PDR (2015).

87 Art. 4, Law on Electronic Signature, Lao PDR (2018).

88 SEACOOP, ICT Policies - Programmes and Research Priorities in the 10 ASEAN Countries, (June 2010), at 12.

89 Ibid

90 Department of Commerce of the US, US Country Commercial Guides - Laos, (2017), at 14; and See also 〈https://aoofficialgazette.gov.la/index.php?r=site/display\&\&id=447〉. 
contributing to socio-economic development while preserving national stability, social peace, order, and justice. ${ }^{91}$ Lao PDR pays attention to the importance of the use of electronic transactions by promoting and supporting electronic commerce and services, public administration, and other electronic transactions to develop the economy and serve society. Furthermore, it also promotes the development of ICT infrastructure, and capacity building to ensure that electronic transactions are safe, transparent, and reliable and to protect consumers. ${ }^{92}$ By the adoption of the law, provisions to regulate electronic transactions/electronic commerce are introduced, and the law is a significant development of the e-commerce legal framework of Lao PDR.

Following the Law on Electronic Transactions, in 2015, Lao PDR has enacted the Law on Prevention and Combating of Cybercrime..$^{93}$ The law provides the principles, regulations, and measures for effectively preventing and combating cybercrimes. Its main objectives are to prevent, combat, limit, and get rid of cybercrimes; to protect databases, servers, and electronic information in order to ensure national stability, peace, and social decorum; and enable to link between the region and globe for socioeconomic development. ${ }^{94}{ }^{95}$ To that end, the achievement of the task on the prevention of cybercrime will also be a significant move to promote the growth of e-commerce and raise confidence and trust in e-commerce use in Lao PDR.

In 2016, a Law on Information and Communication Technology was adopted. ${ }^{96}$ The law lays down principles, regulations, and measures to manage and monitor the use and development of ICT intending to promote the development of ICT and ensure its quality, modernity, speed, and security. Furthermore, it promotes ICT by developing all sectors in order to protect the rights and interests of the state, entities, individuals, and organizations; ensure national stability, social peace, and decorum. ${ }^{97}$ Its main objective is to promote invention and development of ICT infrastructure in the country; facilitate and provide budget for ICT development; develop human resources, along with promoting ICT service and the use of ICT for socio-economic development; and to encourage both domestic and foreign individuals, entities or organizations to invest in development of ICT. Moreover, it also facilitates access to ICT for all people countrywide. $^{98}$

Furthermore, recently in December 2018, Lao PDR adopted Law on Electronic Signature ${ }^{99}$ laying down principles, regulations, and measures to manage and monitor electronic signatures. It aims to ensure rightness, quality, modernity, security, and speed in order to protect rights and interests of state, entities, individuals, and organizations; and ensure national stability, social peace, and decorum; and enable to

\footnotetext{
91 Art. 1, Law on Electronic Transactions, Lao PDR (2012).

92 Art. 4, Ibid, Lao PDR (2012).

93 See 〈https://laoofficialgazette.gov.la/index.php?r=site/display\&id=861>.

94 See Law on Prevention and Combating of Cybercrime, Lao PDR (2015), Art. 1 - Purposes.

95 Art. 4, Ibid, Lao PDR (2015).

96 See 〈https://laoofficialgazette.gov.la/index.php?r=site/display\&id=1136».

97 Art. 1, Law on Information and Communication Technology, Lao PDR (2016).

98 Ibid

99 See 〈https://aoofficialgazette.gov.la/index.php?r=site/display\&id=1495〉.
} 
link the region and globe for socio-economic development. ${ }^{100}$ The electronic signatures are recognized and equally treated as paper-based signatures ${ }^{101}$ which promotes the use of e-commerce and ensures the trust and confidence of both companies and consumers for the use of e-commerce in Lao PDR. It also encourages individuals, entities or organizations of both private and public sectors to build, develop and use electronic signature for their activities, business and services and support the use of electronic signatures and electronic seal to facilitate electronic commerce and service in order to enhance the growth of e-commerce sector. ${ }^{102}$

Furthermore, a Law on Payment System was also adopted in 2017, ${ }^{103}$ Providing DFS regulations. The regulatory framework enables interbank payments, enhances epayment, and reduces the use of cash in the country, fostering overall the development of e-commerce. ${ }^{104}$ However, the appropriate legislation on privacy and the protection of consumers online are still missing, which make Lao PDR doesn't have a full set of laws to regulate e-commerce activities at the moment, and the Government has also lost potential revenue established by the absence of dedicated regulatory framework for ecommerce activities (especially from the so-called Facebook and Instagram shops). ${ }^{105}$

\section{The Alignment of Lao PDR to ASEAN E-Commerce Legal Framework}

Lao PDR has recently extended its interest in e-commerce, promoted by the country's participation in and commitment to the e-ASEAN Framework. This Framework calls for a robust legal and regulatory framework for e-commerce, among other goals. In the past few years, Lao PDR particularly emphasized on preparedness, through different inter-ministerial consultations, for enhancing e-commerce. ${ }^{106}$ As a member of ASEAN, it has also undertaken the ASEAN ICT Master Plan, which expects the guarantee of electronic transactions among other goals within ASEAN partners to become a reality. ${ }^{107}$

Even though Lao PDR is among the ASEAN countries with a nascent ICT infrastructure, $t$ most of the strategies and recommendations set by the 2020 plan of ASEAN has been achieved by the country, especially in regards to policy and legal framework development. The remarkable achievement of its commitments under the eASEAN framework has been ensured by its careful regulatory and legal framework development. However, its legal instruments are still not being used entirely, especially for data privacy and protection of consumers online. ${ }^{108}$

\footnotetext{
100 Art. 1, Law on Electronic Signature, Lao PDR (2018).

101 Ibid

102 Ibid

103 See 〈https://laoofficialgazette.gov.la/index.php?r=site/display\&\&id=1298〉.

104 Art. 4, Law on Payment System, Lao PDR (2017).

105 UNCTAD, Lao People's Democratic Republic: Rapid eTrade Readiness Assessment - Executive Summary, (2018), at viii.

106 UNCTAD, Lao People's Democratic Republic: Rapid eTrade Readiness Assessment, (2018), at 5.

107 Emmanuela Balestrieri, External Evaluation of UNCTAD's E-Commerce and Law Reform Project, UNCTAD (July 2011), at 18.

108 UNCTAD, Ibid at 4.
} 
Besides, Lao PDR achieved those provision of e-Government plan, provision of ICT-supportive law, regulation, and provision of establishment of ICT infrastructure and online services component. To this end, these provisions serve as ICT regulation or policy of the country. It fulfilled the development of ICT infrastructure by the establishment of an e-Government center, and it also fulfilled the online services components through the two-undergoing e-Government projects, namely sectors of health and national internet center. ${ }^{109}$

Under e-ASEAN Framework, Member Countries shall adopt national laws and policies relating to electronic commerce transactions based on international norms; facilitate the establishment of mutual recognition of digital signature frameworks; facilitate secure regional electronic transactions, payments, and settlements, through mechanisms such as electronic payment gateways; adopt measures to protect intellectual property rights arising from e-commerce; take measures to promote personal data protection and consumer privacy; and encourage the use of alternative dispute resolution (ADR) mechanisms for online transactions. ${ }^{110}$ And Lao PDR has fulfilled almost all of the commitments under the framework, to be exact, four out of five points. ${ }^{111}$

As mentioned in the section above, Lao PDR has law on electronic transactions providing provisions to govern electronic activities including e-commerce; law on prevention and combating of cybercrime to ensure the use of electronic information and other cyber consume; law on information and communication technology to promote ICT field and development of ICT infrastructure; law on electronic signature to promote the use of electronic signature and electronic seal and ensure its recognition; and also law on payment system to foster electronic payment. Now, it only lacks appropriate legal instruments on personal data protection and the protection of consumers online. However, this does not mean that Lao PDR does not have any law related to the protection of consumers. It has a law for the protection of general consumers that not only provides provision for specific consumers online but also is construed to cover all types of consumers, including those who are online. ${ }^{112}$ The above account demonstrates that Lao PRD has met the provisions and commitment agreed upon in the e-ASEAN Framework Agreement. However, such legislation, no matter how comprehensive, requires appropriate and serious commitment in their implementation, especially regarding enforcement.

\section{CONCLUSION}

In today's ICT age, e-commerce is a new way of conducting commercial activities, and it is a critical component in increasing economic growth and development around the

\footnotetext{
109 Muhammad Ichsan Fadillah, E-Government in ASEAN: Case Study of Singapore, Indonesia and Laos, at 6.

110 Art. 5, the e-ASEAN Framework Agreement.

111 Muhammad Ichsan Fadillah, Ibid at 6.

112 See 〈https://laoofficialgazette.gov.la/index.php?r=site/display\&iid=545〉.
} 
world. In the last decade, ASEAN has been brought prosperity and wealth to the region through innovation and technology. ASEAN has the third-largest number of internet users in the world, and it is one of the regions that has the fastest growth in internet usage. The major drivers of the growth are its promotion of investment, infrastructure development, and strong regional participation in digital development. However, at the same time, ASEAN still does not have the appropriate legal framework to govern and foster the trans-border e-commerce transactions, a key barrier in facilitating the growth of e-commerce within the region.

Over the last decade, ASEAN ministers, regulators, policymakers, and industry came together and developed ICT landscape and legal framework to support the ecommerce growth within ASEAN. Its first initiative regarding legal e-commerce development is the adoption of ASEAN Vision 2020, then followed by a number of the plan of action introducing legal initiatives concerning e-commerce. More recently, ASEAN adopted an ASEAN Agreement on e-Commerce to facilitate cross-border ecommerce transactions in ASEAN.

Furthermore, ASEAN has developed an e-commerce legal framework by harmonizing the Member Countries' national laws into a regional legal system that respects cultural sensitivities and national sovereignty. However, without a supranational legal instrument, ASEAN can still face legal barrier related to cross border e-commerce, in particular, jurisdiction that raises questions regarding which court may hear and resolve the dispute between contracting parties from two different countries; which law to use; and whether the court judgment obtained in one jurisdiction is enforceable in another jurisdiction.

Lao PDR is actively working to develop its economy, including its digital economy, and it has a noticeable shift in its economic outlook in the previous six or seven years. However, e-commerce in Lao PDR is still new for its people, and the adoption of e-commerce by both consumers and companies remains limited. Despite this, it has made remarkable progress on trade facilitation, even though it needs more efforts towards paperless trade. The rapid growth of e-commerce in ASEAN and all around the world also introduces low cost of trade for Lao exporters and help lower prices for consumers.

Over the past ten years, access to telecommunication services has expanded mainly in Lao PDR, especially mobile phone services. Nevertheless, the continuation of development of the telecommunication sector still yet a lack of a licensing framework, an independent regulator, and a level playing field in the market inhibit the sector from realizing its potential However, there are many initiatives established to enhance the use of e-commerce among SMEs in Lao PDR and the government of Lao PDR now has many laws related to e-commerce transactions. Such legislation requires appropriate and serious commitment in their implementation, especially regarding enforcement, and this will surely be a field well-warranted for study. The law on electronic transactions should be upgraded and form the basis of a dedicated e-commerce law, and it should lead the efforts to adopt appropriate provisions covering data privacy and protection of consumers online. 
As a member of ASEAN, Lao PDR also fulfilled most of the provisions and measures set by the e-ASEAN Framework, mainly the regards of policy and legal framework development. Its fulfillment under the e-ASEAN framework has been ensured by its careful regulatory and legal framework development, and by those provisions of e-Government plan, provision of ICT-supportive law, regulation, and provision of establishment of ICT infrastructure and online services component. However, its legal instruments are not yet being used entirely, especially for data privacy and protection of consumers online, as mentioned in the previous. The country should adopt legislation regarding the matter as soon as possible if it wishes to facilitate and enhance the growth of e-commerce and effectively govern e-commerce activities.

\section{REFERENCES}

Art. 2, ASEAN Agreement on Electronic Commerce.

Art. 5 (1) and (2), ASEAN Agreement on Electronic Commerce.

Art. 1, Law on Electronic Signature, Lao PDR (2018).

Art. 4, Law on Electronic Signature, Lao PDR (2018).

Art. 1, Law on Electronic Transactions, Lao PDR (2012).

Art. 4, Law on Electronic Transactions, Lao PDR (2012).

Art. 1, Law on Information and Communication Technology, Lao PDR (2016).

Art. 4, Law on Information and Communication Technology, Lao PDR (2016).

Art. 4, Law on Payment System, Lao PDR (2017).

Art. 4, Law on Prevention and Combating of Cybercrime, Lao PDR (2015).

Art. 5, the e-ASEAN Framework Agreement (2000)

ASEAN, ASEAN ICT Master Plan, 2015.

ASEAN, "Hanoi Action Plan of Action", 1997 (2.8.1).

ASEAN, "Invest in ASEAN - Single Market and Production Base," (2019), online: 〈http://investasean.asean.org/index.php/page/view/asean-economiccommunity/view/670/newsid/758/single-market-and-production-base.html .

ASEAN Investment Report 2018 - Foreign Direct Investment and the Digital Economy in ASEAN, (Jakarta: ASEAN Secretariat, 2018).

ASEAN Secretariat, "ASEAN Economic Community", (2019), online: $\langle$ https://asean.org/asean-economic-community/〉.

ASEAN Secretariat, "Toward an e-ASEAN," online 〈https://www.asean.org/wpcontent/uploads/images/2012/Economic/TELMIN/TOWARD\%20AN\%20EASEAN.pdf>.

Chea Vannak, "E-commerce Law may not pass in 2018: Ministry, " Khmer Times, (3 May 2018). Online 〈https://www.khmertimeskh.com/485822/e-commerce-law-maynot-pass-in-2018-ministry/>.

Christine Sanderson, EU Forges Ahead on E-commerce, 11 Int'l Tax Rev. 51 (2000). 
Chritopher Findlya, ASEAN and Regional Free Trade Agreements, Routledge London and New York 2015.

Competition Commission of Singapore, Handbook on E-Commerce and Competition in ASEAN, (15 February 2019).

Department of Commerce of the US, "US Country Commercial Guides - Laos" (2017).

Dr. Eliza Mik, Legal and Regulatory Challenges to Facilitating E-Commerce in the ASEAN

Emmanuela Balestrieri, External Evaluation of UNCTAD's E-Commerce and Law Reform Project, UNCTAD (July 2011), at 18.

ESCAP, Embracing the E-commerce Revolution in Asia and the Pacific, (June 2018), pp. 31-32, and its Executive Summary

Fintechnews Singapore, "The State of Fintech in Laos" (2017). online: 〈http://fintechnews.sg/9709/laos/fintech-laos/〉.

Google TEMASEK, e-Commerce SEA 2018: Southeast Asia Internet Economy Hits an Inflection Point, (2018), at 4.

Industrial Structure Council, 2017 Report on Compliance by Major Trading Partners with Trade Agreements - WTO, EPA/FTA, and IIA - Part II. WTO Rules and Major Cases - Addendum 3. E-commerce, the Ministry of Economy, Trade, and Industry, Japan (2017), at 631-634.

Joanne Wong, On Legal Harmonization Within ASEAN, Juris, Vol. 5 (2013/14) Singapore Law Review (2013), at 2.

Marcus Bartley John, Mombert Hoppe, Martin Molinuevo, Konesawang Nghardsysone, and Lillyana Daza-Jaller, Taking Advantage of E-commerce: Legal, Regulatory, and Trade Facilitation Priorities for Lao PDR, World Bank Group (February 4, 2019).

Marn-Heong Wong and Marie Isabelle Pellan, Trade Facilitation: The Way Forward for ASEAN and Its FTA Partners, ERIA Policy Brief, No. 2012-04 (July 2012).

Muhammad Ichsan Fadillah, E-Government in ASEAN: Case Study of Singapore, Indonesia and Laos.

Mr. Somlouay Kittignavong (Acting Director-General of Department of National Authority for Science and Technology), a presentation on ICT Development in Lao PDR - at Expert Group Meeting on regional cooperation on information society in Asia and the Pacific, Bangkok (July 2009).

Nazura Abdul Manap, Alignment of Malaysia and ASEAN Agreement on ICT Law: A review. Contemporary Issues in South-East Asia Countries. Brawijaya Law Jornal, Vol. 2(S) No.l (2015), at 4.

OECD, ERIA, ASEAN SME Policy Index 2018 - 15. Lao PDR: 2018 ASPI Country Profile, (2018), pp. 301, 304.

OECD, Economic Outlook for Southeast Asia, China, and India 2018: Fostering Growth Through Digitalisation, OECD Publishing, Paris (2018), pp. 21 and 45.

OECD, Structural Policy Country Notes for Emerging Asia - Economic Outlook for Southeast Asia, China, and India 2014: Beyond the Middle-Income Trap, (2013). 
Rodolfo Noel S. Quimbo, "The e-ASEAN Legal Framework and Its Challenges" Harmonized development of legal and regulatory systems for e-commerce in Asia and the Pacific: Current challenges and capacity-building needs (2012).

Samtani Anil, Electronic Commerce in Asia: The Legal, Regulatory and Policy Issues, Int. Journal of Law and Information Technology, Vol.9 No. 2, Oxford University Press (2001), at 97 .

SEACOOP, ICT Policies - Programmes and Research Priorities in the 10 ASEAN Countries, (June 2010), at 12 .

Simon S.C. Tay, Jesus P. Estanislao, Hadi Soesastro, Reinventing ASEAN, Institute of Southeast Asian Studies, Singapore (2001), at 144.

Sum Manet, "E-Commerce Law a Realty Soon," Khmer Times, (7 November 2016). Online 〈https:/www.khmertimeskh.com/61899/e-commerce-law-a-realty-soon/〉.

The Preamble, ASEAN Agreement on Electronic Commerce; See also 〈https://asean.org/asean-economic-community/sectoral-bodies-under-thepurview-of-aem/e-Commerce/s.

UNCTAD, Lao People's Democratic Republic: RapideTrade Readiness Assessment, (2018).

UNCTAD, Review of E-commerce Legislation Harmonization in the Association of Southeast Asian Nations, (2013).

WTO, Joint Statement on Electronic Commerce, WT/L/1056, (19-0423), Brussels (25 January 2019), online: 〈https://trade.ec.europa.eu/doclib/docs/2019/january/tradoc_157643.pdf〉.

Xiudian Dai, e-ASEAN and Regional Integration in South East Asia, University of Hull, UK (2007).

Zhang Tuo, Yu Hui, and Rong Zhongxia, Report on China-Laos Cooperation Opportunities under the Belt and Road Initiative in 2018, Xinhua Silk Road Department (2018). 
396 | ASEAN E-Commerce Legal Framework and Alignment of Lao PDR: A Review

This page is intentionally left blank 